UDC 314.7:351

JEL O15

DOI 10.26906/EiR.2021.1(80).2233

\title{
THEORETICAL FOUNDATIONS OF MIGRATION POLICY
}

\author{
Iryna Chernysh*, Doctor of Sciences (Economics), Professor \\ Yuliia Solovei**, PhD student \\ National University «Yuri Kondratyuk Poltava Polytechnic»
}

\author{
*ORCID 0000-0001-6565-5292 \\ **ORCID 0000-0003-1212-4791 \\ (C) Chernysh I., 2021. \\ (c) Solovei Yu., 2021.
}

Стаття отримана редакиією 19.03.2021 p.

The article was received by editorial board on 19.03.2021

Introduction. One of the typical features of the modern era is an increase in the scale, variety of types and directions of international migration. International movements of the population have become an important factor in social transformations in countries of destination and origin of migrants, and affect interstate relations. These conditions have led to an increase in the importance of migration policy as an obligatory component of the activities of national governments, interstate associations, and the entire world community. As a result, the relevance of scientific research on migration policy, which has theoretical and practical significance, has increased. Migration policy, as well as migration processes, is studied on a multidisciplinary basis. The long dominant position of economics in the study of migration, the most widespread study of migration policy from the standpoint of political economy, where the main issue is the economic benefits and losses from migration and, hence, the political decisions made as a result of their assessment. At the same time, a number of theoretical models for the analysis of migration policy are used in political science, sociology, and international relations. The review of the most common of them, presented in the article, gives grounds for the conclusion that they all complement each other, but they cannot offer an exhaustive explanation of the process of formation of migration policy and its content. Although a coherent theory of migration policy does not exist, the scientific approaches used in modern research lead to several conclusions that seem important for practical policy. First, migration policy is a product of the political system, not just a reflection of economic or demographic circumstances. Secondly, it is formed not only by the state, but also by other public institutions, the vision of which may differ. Therefore, an effective migration policy requires the coordination of the interests of the state and the actual migrants, local communities, political parties, and non-governmental organizations. Third, since migration occurs between two or more states, reconciliation of interests is also necessary at the international level.

Analysis of recent research sources and publications. In modern conditions, many domestic and foreign scientists are working on this problem, such as A. Betts, M. Weiner, E. Meyers, J. Hollifield, A. A. Zolberg, V. Yevtukh, E. Libanova, O. Piskun, S. Pyrozhkov, A. Pozniak), O. Piatkovska, S. Chekhovych, B. Yuskiv, et al. studied the current migration problems of the country, offered their own vision of their settlement by means of state policy. At the same time, the work of Ukrainian scientists was mainly of a practical direction and to a lesser extent related to the theoretical aspects of the problem.

Results. One of the typical global processes now is the growing scale of international population movements. The volume of migration is rapidly increasing in both absolute and relative terms. According to UN estimates, there are at least 258 million international migrants in the world, accounting for $3.3 \%$ of the world's population.

At the same time, the composition, nature, and direction of the movements are changing. As a result, the impact of international migrations on the demographic situation, ethno-national structure of the population, the socio-economic development of the countries of the world, their international relations is significantly enhanced. Social shifts caused by migration determine the transformation of migration policy into an obligatory component of the activities of national governments, interstate associations, and the entire world community. 
Before gaining independence, Ukraine was artificially separated from global migration processes. Having opened up to the world, our state quickly turned into a country-supplier of migrants abroad. At the same time, it receives migrants and refugees, and is a transit one. This has put forward an urgent need to develop a migration policy of the state, adequate to modern requirements, to provide legislative and administrative means of its implementation. In such conditions, the study of the essence and features of migration policy, analysis of theoretical achievements in the relevant area has both scientific and practical significance, is an important prerequisite for a well-grounded approach to improving the state policy in the field of migration.

A lot of regional agreements on the regulation of migration processes have been made in the world. The integration of migrants into society takes place at the local level, so the relevant issues naturally remain within the competence of individual countries. Like any other global process, international migration not only opens up new opportunities, but also creates new problems. The challenges caused by the social shifts caused by migration led to the rapid politicization of the migration sphere, the transformation of migration policy into an obligatory component of the activities of national governments, interstate associations, and the entire world community.

In the modern world, migration processes have acquired rapid quantitative and qualitative changes, the means and mechanisms of their regulation are becoming more important. Migration policy is the main element of migration management.

Having created a clear migration policy, migration movements can be used as a positive potential in the interests of the country's development; the ability of state authorities to control migration processes is a prerequisite for the successful development of international cooperation in the field of migration.

Most scientists consider migration policy as a system of measures aimed at achieving the desired intensity and composition of migration flows.

The scientific understanding of migration policy as an important factor in migration processes took place in the 1980s and 1990s. It owes much to the works by American scientist A. Zolberg. He rightly noted that all countries where people want to enter usually restrict entry. Thus, it is their policies that determine whether population movements will take place and, if so, what they will be. This applies not only to normalized, but also to illegal migration, because the very concept of illegal migration arises and acquires meaning only in the context of the rules and procedures established by the state, which, in case of illegal arrival or stay, are violated.

Analysis of the migration policy of different states gave A. Zolberg grounds for concluding that international migration is primarily a political process, a consequence of the organization of the world in the form of sovereign states. It consists in the transfer of a person from the jurisdiction of one state to the jurisdiction of another, which leads to a change in its membership in one or another political community. According to the migration policy, it covers not only the rules and procedures for entry and exit across state borders (migration policy in the narrow sense), but also all aspects of the acquisition, preservation, loss or voluntary refusal of membership in this political community in all its aspects - political, social, economic, cultural [5].

Researcher Oleksandr Khomra argued that "migration policy is a complex of developments and measures aimed at forming the necessary flows and the required intensity of population migration" [1].

In the context of globalization, migration policy acts as an aspect of international politics. Therefore, it is worth paying attention to the definition, according to which migration policy is a system of political measures, regulations, legislative acts and agreements (first bilateral and then multilateral) between states to regulate migration flows.

Migration policy is an independent direction of state policy, this direction is intertwined with its other components, both domestic and foreign policy. It is an element of population policy and, as well as one of the means of the desired population and labor force - part of socio-economic policy, an instrument for achieving its goals. Migration policy, at the same time aimed at planning the movement of the population, and performs the functions of control over it, is the state's response to spontaneous movements of people.

Migration policy research, like migration research, is usually conducted at two levels - international and national. At the international level, migration policy is considered within the framework of the international system, interpreted as a consequence of the discrepancy between the needs of the global market and geographically limited state entities. This is a reflection of the struggle between two groups of interests: the needs of the global economy in a wide supply of labor and efforts to maintain differentiated conditions of wages, social security, and cultural homogeneity within the state. 
Supporters of the international approach emphasize that the effectiveness of measures by national states depends on the current international legal regime, namely international agreements and agreements between them, in particular, human rights. That is, the actions of states are limited by the principles, rights and obligations fixed in international legal documents. K. Codagnone noted that this approach allows us to determine, first of all, the framework for making decisions on migration, but not their content, since, despite the declaration of the principles of liberalism and respect for human rights by most states of the world, they differ significantly both in their interpretation and readiness. or the ability to fully comply with them [3].

Scientists who study the national approach study the internal factors of the formation and evolution of the migration policy of states, such as the socio-economic situation, demographic development, the ethnic composition of the population and its dynamics, and the like. Usually they are considered in two dimensions - national and situational-political [4].

At the national level, the study provides for the study of the impact of migration processes on the socio-political position of the state and the identity of its citizens, the system of intrastate relations, political culture, and the like. In the first place is control over migration flows, the establishment of rules for entry, exit, stay, that is, state migration policy in the narrow sense. The situational political dimension is associated with the study of national security and threats caused by migration. Migrants and their associations are viewed as political actors who are directly involved in the political life of the state, as well as subjects of influence of political forces in both countries of origin and destination. Within the framework of this dimension, the political roles of diasporas and transnational social networks that have developed due to migration are studied, today these networks and diasporas are of great importance in the countries of residence and origin, they can lobby the interests of the native country, support certain political forces in it, and influence the electoral choice. the like.

Migration policy, migration processes and migration are studied on a multidisciplinary basis. Longterm dominant position in the research of migration of economic science, more attention has been focused on the analysis and study of migration policy from the standpoint of political economy, the main point of which is the economic benefits and losses from migration and, accordingly, the political decisions taken as a result of their assessment. Considering migration policy in political science, pluralistic, institutional and neocorporative models are most often used. Sociology and psychology focus on explaining migration policy in terms of national identity. The field of international relations offers the following approaches as realistic, liberal, constructivist. All these theoretical models complement each other, although none of them is capable of providing an exhaustive answer to the question of the factors in the formation and content of the state's migration policy.

An attempt to get out of the coordinates of the interests of certain social groups, as E. Meyers writes, is an explanation of migration policy from the standpoint of national identity [5]. Supporters of this approach believe that the unique history and tradition of each country, the concept of citizenship, the concept of citizenship reigns in it, the widespread in society understanding of its identity are decisive for the content of migration policy, and national mythology is an important factor in shaping the attitude of the population towards newcomers [6].

Perception of aliens largely depends on cultural homogeneity or heterogeneity of society and differs in states where nations are formed by immigrants (USA, Canada, Australia), and states where carriers of local culture make up the majority and live for generations; in countries with a multi-ethnic and mono-ethnic composition of the population. Colonial ties are important, as well as the concept of citizenship: where a nation is viewed as a political and not an ethnic unity, the attitude towards migrants is more tolerant [7].

Within the framework of this approach, the development and changes in the migration policy of this or that state reflect changes in national identity, and differences in migration policies of different countries are due to different understandings of it. The main disadvantage of explaining migration from the standpoint of national identity is the inability to explain why countries that are completely different in their historical experience and cultural characteristics form similar or even identical migration policies, an example of which is the formation of a common EU migration policy.

The relationship between migration and foreign policy was first emphasized by M. Weiner. Firstly, the attitude of the state towards migration often affects its international relations; secondly, the rules for admitting foreigners to a sovereign territory may reflect relations with the country of their citizenship, be the result of a demonstration of their position or a means of forming an international image; thirdly, migrants are capable of influence the international policy of the country and of origin and destination [6].

According to A. Betts, within the framework of a realistic approach, in order to understand migration policy, several hypotheses must be taken into account. First, migration is important for the state only as a 
factor of its security, therefore, most of the scientific works of the supporters of this approach are devoted specifically to threats to national security, including the terrorist threat, is associated with migration. Secondly, the migration policy is influenced by conflicts between states, which are viewed as a consequence of the imbalance of power in the international arena. They, in particular, can lead to restrictions on the movement of the population, or, conversely, to activate them [7].

Thus, the connection between conflicts and migration policy is clearly confirmed by the example of Israel, where the promotion of immigration is a component of the state's security policy in the face of constant confrontation with the Arab world.

In addition, since the interests of the state are primarily in the strengthening of military power, there are no altruistic and ethical motives in its actions, in particular, the asylum of foreigners is provided exclusively in accordance with their own interests. This explains the positive attitude of Western democracies towards asylum seekers from the countries of the Eastern bloc during the Cold War.

Conclusions. So, after analyzing the research of scientists, we can say that the only correct theory of migration policy does not yet exist. Scientific approaches and developments used in modern research lead to certain conclusions that seem to be relevant for practical policy. Let us also highlight the fact that migration policy is a product of the political system, and not just a manifestation of economic or demographic circumstances.

Migration policy is formed not only by states, but also by other public institutions, the concept of which may be different. Therefore, for the effectiveness of migration policy, the interests of migrants, local communities, non-governmental organizations and the state must be aligned. So migration is carried out between states, and coordination of interests at the international level is also required.

Therefore, summing up the above material, in order to improve migration policy, a clear understanding of the mechanisms of its formation is necessary. The migration policy of Ukraine in the field of migration should not only regulate migration processes, but also influence the development of the country, taking into account global trends and promote Ukraine's integration into the international community as an independent, progressive and civilized state. The main promising directions, possible for implementation, will be proposed by us in further scientific research.

\section{REFERENCES:} $146 \mathrm{p}$.

1. Homra A. (1979). Population migration: theory issues, research methods. K., "Naukova Dumka".

2. Zolberg A. (1999). The Matters of State: Theorithing immigration policy. The Handbook of International Migration / Ed. by C. Hirschman, P. Kasinitz, J. DeWind. NY, Rassel State Foundation. P. 7193.

3. Meyers E. (2000). Theories of international migration policies - a comparative analysis. International mig- ration review. Vol. 34. №. 4. P. 1247-1251.

4. Stalker P. (1994). The Work of Strangers: A Survey of International Labour Migration. Geneva, International Labour Office. 330 p.

5. Money J. Comparative Immigration Policy. Access mode:

http://wwwisacompss.com/info/samples/comparativeimmigrationpolicy_sample.pdf (accessed 25.03.2021).

6. Weiner M. (1984). On International Migration and International Relations. Population and Development Review. No. 3. P. 441-455.

8. Betts A. (2009). Forced migration and global politics. Oxford, Willey-Blackwell. 216 p.

\section{УДК $314.7: 351$}

\section{JEL O15}

Черниш Ірина Володимирівна, доктор економічних наук, професор, директор Навчальнонаукового інституту фінансів, економіки та менеджменту. Соловей Юлія Григорівна, аспірантка. Національний університет «Полтавська політехніка імені Юрія Кондратюка». Теоретичні основи міграційної політики. Однією 3 типових рис сучасної епохи $\epsilon$ наростання масштабів, урізноманітнення видів та напрямів міжнародної міграції. Міжнародні переміщення населення перетворилися на важливий чинник суспільних трансформацій у країнах призначення і походження мігрантів, впливають на міждержавні стосунки. Саме ці умови спричинили зростання значимості міграційної політики як обов'язкової складової діяльності національних урядів, міждержавних об’єднань, усієї світової співдружності. Унаслідок цього посилилася актуальність наукових 
досліджень міграційної політики, що мають теоретичне й практичне значення. Міграційну політику, так само як і міграційні процеси, вивчають на полідисциплінарній основі. Унаслідок тривалого панівного становища економічної науки в дослідженнях міграції, найбільшого поширення набуло вивчення міграційної політики з позиції політичної економії, де основним питанням $є$ економічні вигоди та втрати від міграції й звідси політичні рішення, ухвалені в результаті їх оцінювання. Разом 3 тим низку теоретичних моделей аналізу міграційної політики застосовують у політології, соціології, міжнародних відносинах. Огляд найпоширеніших із них, поданий у статті, дає підстави для висновку, що всі вони доповнюють одна одну, проте не можуть запропонувати вичерпні пояснення процесу формування міграційної політики та її змісту. Хоча цілісної теорії міграційної політики не існує, наукові підходи, що використовуються в сучасних дослідженнях, дають змогу зробити кілька висновків, які видаються важливими для практичного впровадження. По-перше, міграційна політика $\epsilon$ продуктом політичної системи, а не лише відображенням економічних чи демографічних обставин. По-друге, вона формується не тільки державою, а й іншими суспільними інститутами, бачення котрих може відрізнятися. Тому дієва міграційна політика потребує погодження інтересів держави і власне мігрантів, місцевих громад, політичних партій, неурядових організацій тощо. По-третє, оскільки міграція відбувається між двома або й більше державами, погодження інтересів є необхідним також i на міжнародному рівні.

Ключові слова: міграційна політика, теоретичні моделі, напрями аналізу.

UDC 314.7:351

JEL O15

Chernysh Iryna, Doctor of Sciences (Economics), Professor. Yuliia Solovei, PhD Student. National University «Yuri Kondratyuk Poltava Polytechnic». Theoretical Foundations of Migration Policy. The article is devoted to the definition of one of the typical features of the modern era - an increase in the scale, a variety of types and directions of international migration. International movements of the population have become an important factor in social transformations in countries of destination and origin of migrants, and affect interstate relations. These conditions have led to an increase in the importance of migration policy as an obligatory component of the activities of national governments, interstate associations, and the entire world community. As a result, the relevance of scientific research on migration policy, which has theoretical and practical significance, has increased.

Key words: migration policy, theoretical models, directions of analysis. 